\title{
Gender-Benders': Sex and Law in the Constitution of Polluted Bodies
}

Dayna Nadine Scott

Osgoode Hall Law School of York University, dscott@osgoode.yorku.ca

Source Publication:

Feminist Legal Studies. Volume 17, Number 3 (2009), p. 241-265.

Follow this and additional works at: https://digitalcommons.osgoode.yorku.ca/scholarly_works

Part of the Environmental Law Commons, and the Law and Philosophy Commons

(c) $(i) \Theta \Theta$

This work is licensed under a Creative Commons Attribution-Noncommercial-No Derivative Works 4.0 License.

\section{Recommended Citation}

Scott, Dayna Nadine. "Gender-Benders': Sex and Law in the Constitution of Polluted Bodies." Feminist Legal Studies 17.3 (2009): 241-265.

This Article is brought to you for free and open access by the Faculty Scholarship at Osgoode Digital Commons. It has been accepted for inclusion in Articles \& Book Chapters by an authorized administrator of Osgoode Digital Commons. 


\title{
' 'Gender-benders' ' : Sex and Law in the Constitution of Polluted Bodies
}

\author{
Dayna Nadine Scott
}

Abstract This paper explores how law might conceive of the injury or harm of endocrine disruption as it applies to an aboriginal community experiencing chronic chemical pollution. The effect of the pollution in this case is not only gendered, but gendering: it seems to be causing the 'production' of two girl babies for every boy born on the reserve. This presents an opening to interrogate how law is implicated in the constitution of not just gender but sex. The analysis takes an embodied turn, attempting to validate the real and material consequences of synthetic chemicals acting on bodies - but uncovers that finding a harm in a declining sex ratio depends on a static conception of the human form, based on unfounded assumptions of 'naturalness' and 'normalcy'. Elizabeth Grosz's theory of 'becoming' offers a compelling challenge, essentially pointing to the conclusion that we should find harm where we find illness and suffering and not simply where we find difference. At the same time, we cannot discount the political economy of the pollution: the paper concludes by returning the focus to the role of power, colonialism and the state in the perpetuation of the pollution on the landscape.

Keywords Canadian First Nations community - Chemical pollution • Endocrine disruption - Feminist theory of the body - Gendered harm • Political economy of pollution $\cdot$ Tort law

\section{Introduction}

For the residents of Aamjiwnaang First Nation, living in the shadow of Canada's 'Chemical Valley', a recent epidemiological study confirmed what they had suspected for years - that the community's sex ratio (the number of boy babies born relative to the number of girls) is declining at an alarming rate. It is widely speculated that chronic exposure to toxic chemical pollution, specifically a group of endocrine-disrupting chemicals provocatively nicknamed the "gender-benders", is responsible. This paper examines how law might conceive of the 'harm' or 'injury' that has been visited on the Aamjiwnaang community, and demonstrates that, for endocrine disruption, the impact of 
pollution is not only gendered, but in the context of reproduction, it is gendering. This presents an opening to explore, through the work of feminist theorists of the body, how law is implicated in the constitution and construction of not just gender, but sex. On the Aamjiwnaang First Nation reserve, it is clear that pollutants act on bodies, pollutants actively produce bodies, and the legal regime that facilitates that pollution, I argue, is implicated in this. Thus law, here, operates not just in the social realm, it veers into the biological. The pollution, and the law, is actually acting on, or interfering with, bodiesmaterial, corporeal reality.

The paper seeks to render visible the complex nature of contemporary pollution harms and to expose the inequities through which the 'wounds' flowing from pollution are distributed. Understanding the nature of contemporary pollution is essential to the crafting of new strategies to fight it. In particular, the paper seeks to destabilise the tendency in the environmental justice movement to conceptualise harms on the basis of unquestioned assumptions about 'naturalness' and 'normalcy'. For example, the problem of endocrine disruption and the declining sex ratio presents an opportunity to unpack the concept of sexual difference-and confront the orthodoxy that sexual identity occurs 'naturally' as a binary category.

But, following the line of analysis that has not just gender but also sex as socially and culturally constructed fails to give effect to the embodied reality of living with chronic pollution. It fails to recognise that bodies are reducible to a basic materiality, and therefore it discounts the real and material consequences that synthetic chemicals are having within bodies. Still, even on an embodied analysis, finding harm in endocrine disruption and a declining sex ratio depends on a static or fixed conception of bodies, nature, and the human form. My reading of Elizabeth Grosz and her theory of 'becoming' posits a more tolerant attitude to a changing human form. Openness to an indeterminable direction for bodies again problematises, from a completely different perspective, the prospect of assigning 'harm' to a declining sex ratio. At the same 
time, I cannot and will not discount the blameworthiness of the pollution and the political, economic and historical conditions under which it is perpetually present on the Aamjiwnaang First Nation reserve, and the way that law is implicated in its continuance.

The paper consists of four parts. In the first part, I chronicle the contamination of the Aamjiwnaang First Nation, and describe how the struggle of this small reserve community, and their campaign against endocrine disruption, has garnered the attention of environmental justice activists worldwide. In the second part, I explore the conceptual inability of tort law to conceive of the harm or the 'injury' that is visited on the Aanishinaabek of Aamjiwnaang, including what the gender dimension of that harm might be. In the third part, I explore the work of feminist theorists of the body, most notably Elizabeth Grosz. This analysis reveals how competing conceptions of sex and gender expose the unexamined assumptions about 'naturalness' and 'normalcy' that ground the claims of environmental justice activists related to the harms of endocrine disruption. Again, I encounter conceptual difficulties in finding 'harm' in the declining sex ratio, despite the expectation that an embodied approach might take seriously the biology of the problem so as to find harm. In the fourth and final part, I conclude with some reflections on the political economy of pollution, the nature of 'harm' and the nature of 'difference', and offer some ways to move forward with environmental justice organising and feminist environmental health activism in light of these critical lessons.

\section{The Contamination of Aamjiwnaang First Nation}

The Aamjiwnaang First Nation is a community of approximately 900 Aanishinaabek people living on a reserve located immediately adjacent to Sarnia's notorious 'Chemical 
Valley'. This area of southwestern Ontario, located at the southern tip of Lake Huron, bordering Michigan, USA, houses one of Canada's largest concentrations of industry, including several large petrochemical, polymer, and chemical industrial plants, as well as coal-fired utilities on both sides of the border (MacDonald and Rang 2007). In recent years, residents of the reserve began to wonder about why they were starting to require two softball teams to accommodate the girls on reserve, and they could barely field one team of boys. ${ }^{1}$ Soon, they had documented a marked decrease in the number of males born into their community. An investigation was launched to explain this phenomenon, and the Aamjiwnaang First Nation now has the unwelcome distinction of the world's lowest documented birth ratio (Colihan 2008).

The study suggests that the noted decline in sex ratio could be correlated with the community members' exposure to industrial pollutants (Mackenzie et al. 2005). Other studies conducted in this region have found changes in the sex ratios and reproductive ability of fish, bird and turtle populations, which are thought to be due to exposures to endocrine-disrupting chemicals. Endocrine disruptors are said to have a hormone-mimicking effect. They may induce long-term effects upon lowdose exposures in susceptible developmental phases. There are a number of competing hypotheses for how, specifically, these environmental contaminants disrupt the human endocrine system, and how they might be influencing sex ratio. The hypothesis with the most traction seems to be that interference with a mother's hormonal milieu at key developmental stages very early in a pregnancy can induce sex-specific mortality in miscarriage. Essentially, the hypothesis is that embryos that would become boy babies are being disproportionately lost in early miscarriages, usually occurring before the prospective mother even becomes aware that she may have been pregnant.

Advocates railing against chronic pollution and contamination are increasingly identifying with and being inspired by the environmental justice movement. These activists see "connections between social welfare and the environment, pollution and 
the home, and pollution and discrimination, that have gone unnoticed (or conveniently ignored) by mainstream environmentalists" (Verchick 1996, p. 46). A central focus is the notion of disproportionate burdens - the claim that while pollution is everywhere, it is most easily found in a few choice places, particularly those inhabited by the poor, the racialised and the marginalised (Luke 2000). The focus of organising is on the fundamental power differential that exists between the polluters and the polluted. As a result, many activists in the environmental justice movement want to be able to say unequivocally that the "gender-bending" of endocrine disruption is a new, dramatic and horrifying harm. But our ability to categorise the declining sex ratio on the Aamjiwnaang First Nation as a 'harm' or 'injury' in law, as I will demonstrate, is fraught with difficulties.

The central claim of the environmental justice movement - that some of us live more downstream than others-is a stark and obvious truth in Sarnia's Chemical Valley. Talfourd Creek gathers its waters in an industrial corridor home to $40 \%$ of Canada's chemical production before it meanders through the Aamjiwnaang reserve and empties into the St Clair River. There are 62 large emitting industrial facilities within $25 \mathrm{~km}$ of the reserve (MacDonald and Rang 2007). In 2005 there were 5.7 million kilograms of toxic air pollutants released from the facilities on the Canadian side of the border alone. The Aamjiwnaang First Nation, confined to a small portion of their traditional territory by colonialist law, has been steadily surrounded by industry and many residents now feel that it is being slowly choked out by the legacy of a century of petrochemical production (Scott 2008).

Contamination of their bodies and their traditional territory has had an enormous emotional effect on the community. While the skewed sex ratio may be a potent symbol of the complexity of contemporary pollution harms, it is by no means the only manifestation of the pervasive, diffuse and body-altering pollution that the residents report. They experience elevated rates of cancer and diabetes, developmental and 
attention-deficit disorders, asthma and other respiratory ailments. The recent years have witnessed a building anger as residents learn of the extent of their health problems and the mounting evidence linking those problems to the actions of their industrial neighbors. ${ }^{2}$ They are a deeply injured community.

Identifying the Injury

To find an injury in law we need to identify a cause and effect relationship that culminates in a tangible harm. Not only is the causality contested in this case, but a tangible harm is elusive. Thinking specifically of the issue of the declining sex ratio, how can we characterise what has been lost in the Aamjiwnaang situation? Only chances-chances to welcome sons. No one mother could ever prove that she specifically was harmed; that she specifically should have conceived a boy. No child has been harmed. But it is difficult to fathom that there is no harm being done. It is clear that there is wounding to be accounted for.

Cultural anthropologist Sarah Lochlann Jain employs the term 'wound' to capture the sense that harms exist out there in the world that are not contained in the legal notion of 'injury' (2006, p. 6). And, as she reminds us, “wellness and wounding will always be at play within various cross-cutting hierarchies" preexisting in our society (Jain 2006, p. 5). “[W]ounding itself”, Jain states, “brings a mode of attention to objects into being...objects only emerge as separate from the [agent] when something goes wrong" (2006, p. 5). It is as if the chronic chemical pollution in the streams, rivers, air, and soil of the Aamjiwnaang reserve is suddenly rendered visible by the duly documented epidemiological study of the plummeting sex ratio. And further, as I will show, it is only through the application of cultural assumptions about the 'naturalness' of a binary category of sex, and a 'normal' distribution or balance between two distinct 
sexes, that we may characterise what is happening to the Aamjiwnaang community as a 'harm' at all.

How should we understand the harm or the injury that the Aamjiwnaang community has suffered, and continues to suffer? Or, as a colleague (half-jokingly) put it to me, "What's the harm in a few less men?" Why does this sex ratio dynamic, a declining proportion of boys born into a community, present a challenge to law's conventional understandings of harm and risk? In this part, I employ Jain's critique of 'injury' in law to unpack the issue of harm presented by this particular environmental health problem.

Injury in Law

In Jain's conception, injury in law is a right not to be harmed through another's negligence (2006, p. 6). Tort law has morphed into an "obligatory passage point" on the way to recognising injury $(2006$, p. 1). It is seen as a way to "negotiate responsibilities", or as the "back door, private way of regulating dangerous [activities] when the government refuses to do so" (2006, p. 2). In other words, according to Jain, the function of tort law is not only to compensate the injured, but to do the political and social work of deciding what will count as injury and to make physical injuries material (2006, p. 2). It is fundamentally about the distribution of responsibility in society.

Tort law's prerequisite, however, is that the (injured) "physical body...come[] to the table as a preceding artefact being reclaimed after having been unjustly altered" (2006, p. 6). It is offered up as collateral for the "justness" of a legal logic through which certain practices, like the discharge of toxic chemicals into the environment, in theory, become morally reprehensible or unacceptable. On top of the inability of the Aamjiwnaang community to produce a single or distinct injured body, “unjustly altered", 
the chronic low-dose exposures to pollution that are suspected to be responsible for the 'injury' are (for the most part, at least) legally sanctioned and permitted. The actions of the corporate polluters, instead of being seen as morally reprehensible, are in fact state-sanctioned acts of productive economic activity.

In this respect, law appears ambivalent to the endocrine-disrupting pollution. The basis upon which the prevailing regulatory approach rests is that pollution is permitted according to certain specified limits or standards set down in a regulation, and in the rare case where this legally-sanctioned pollution results in proven harm, the state relies on tort law to step in and provide compensation. ${ }^{3}$ Civil remedies between individuals were long ago dismissed as being ineffective as legal tools for the general systemic control of pollution (although they continue to be relied upon to 'pick up the slack' when things go wrong). A regulatory approach was judged to be more effective.

The regime is typically administered by technical agencies staffed with scientific and engineering experts focused on determining the 'safe' levels of various pollutants in the environment. The job is one of identifying pollution sources, bringing them under permit, and then controlling the quality and quantity of emissions discharged through the terms and conditions of the permit. The underlying assumption is that the natural environment can be used to assimilate (dilute and cleanse) the waste generated through human activity. This is largely still the basis for the contemporary regulatory regime: typically, the governing statute contains a general discharge prohibition on contaminants in combination with the issuance of permits for emissions in accordance with a certificate issued by the relevant authority. ${ }^{4}$ The certificate is a legally binding licence that sets out the conditions under which a facility can operate, including, often, the maximum permissible contaminant emission levels.

The ambivalence of our law, then, derives from the continued prominence of the understanding of environmental health harms as incidental to, and not central to, 
industrial production. Any harm caused by legally sanctioned, permitted pollution (as most of it is in Sarnia's chemical corridor) is treated as a by-product or an accidental side effect of the economic activity. It remains "unintentional". And yet, pollution is a "fixed feature" of modern economies (Luke 2000, p. 248). As Richard Lazarus has noted, "pollution in our regulatory environment finds the pathway of least resistance. It finds those places where the laws are least enforced and least understood" (1997, p. 714). The production of chemicals, the refining of oil, and the generation of electricity in the Sarnia corridor has harm and wounding embedded in it. It is equally the production of pollution.

\section{Wounding}

"Wounds adhere differently to different people" (Jain 2006, p. 58). And the act of wounding, as Jain shows, focuses attention on things which were previously not clearly in view. But the fact that the chronic contamination of the Aamjiwnaang territory was only rendered visible by the sudden notoriety of having the world's lowest birth ratio, is also largely due to the nature of toxic chemical pollution. It is invisible. The 'risks' associated with it are virtually undetectable without scientific investigation. They manifest as "harms caused by molecules" (Cranor 2006, p. 12). To understand the mechanics of endocrine disruption, for example, the way that certain chemicals mimic hormones in the body by binding with available receptors and influencing gene expression, we are forced to rely on biomedical ways of knowing. ${ }^{5}$ The consequences of exposure tend to eventually manifest themselves in ways that start from within the body and work their way out (Erikson 1991). Further, the latency period associated with many contemporary environmental health risks underscores their psychological impact in that it renders the experience of risk unbounded: “an 'all clear' is never sounded” (Erikson 1991, p. 21). Bodies contain 
chemicals banned years before the individual's birth; contamination can be extremely long-lasting, and can be passed down from generation to generation. For example, in part because it is widely accepted among epidemiologists that exposures to toxic chemicals in one generation may produce effects in the next, no one can tell the Aamjiwnaang community whether they face a present danger, or are experiencing the latent manifestation of exposures long past: as one Band member states, "was it me, was it my dad, my mom?...we don't know who's been

exposed". 6

The Gendering Effect of Endocrine Disruption

The gender dimension of the 'harm' experienced by the Aamjiwnaang community is as difficult to demonstrate as it is to dismiss. The impact of pollution seems not only to be gendered, but gendering. By this I mean that the endocrine disruptors do not just dole out their environmental health horrors disproportionately as between men and women, or girls and boys, they actually seem to be driving whether we get girls or boys. The pollution is feared to be actively producing gender. At the same time, its impact intersects directly with colonial histories of health and justice.

The Aamjiwnaang experience is marked by the individual trauma of repeated miscarriage and the collective loss of a viable future. The skewed sex ratio, conceptualised as a 'harm', is one that is both visited specifically on women, and felt by the community as a whole. As Joanne Conaghan has argued and the previous part has made clear, 'harm' is an 'unstable, slippery concept, highly dependent on context and very much the subject of interpretation"' (2002, p. 320). But at the same time, as Robin West has argued, the question of what constitutes a 'harm' is central to legal theory (1997, p. 94). Further, the question is a critical one for feminists: as Martha Chamallas and Linda Kerber have shown, tort law traditionally falters when it is faced with claims 
based on harms for which there is no "precise masculine analog" (1990, p. 814).

According to Robin West's 'connection thesis', women's material connection to future human life necessarily produces a gendered notion of harm (1988). The prospect of pregnancy, of contributing to a future generation, marks the key difference between women and men. Underlying all branches of feminist theory, West says, is the notion that “women's existential state...is grounded in women's unique potential for physical, 'material connection' to human life" (1988, p. 14). This is the one place where even feminism's divisions dissolve: we all come together, she says, on the "discovery or rediscovery of the importance of women's fundamental material difference from men"' (1988, p. 14).

Women are actually or potentially materially connected to other human life. Men aren't. This material fact has existential consequences...[it] defines women's subjective, phenomenological and existential state, just as surely as the inevitability of material separation from the other defines men's existential state. (West 1988, p. 14)

Somewhat predictably, then, Aamjiwnaang mothers and potential mothers, even if they are not uniquely 'harmed', are usually identified as the medium through which the poisoning occurs: they are seen as sites of contamination. The notion of the mothers as mediums for the pollution is reinforced by various strategies of resistance that have been employed by residents of the Aamjiwnaang community themselves, including "body burden" testing and "body mapping" exercises, and even self-help strategies such as leaving the reserve when trying to become or once becoming pregnant. ${ }^{7}$ This is true even as the epidemiological evidence remains contested as to the significance of the maternal influence. In fact, the scientific literature that links endocrine disruptors with skewed sex ratios focuses on male and female reproduction, with researchers often unwilling to make a call at this point as to which is the more 
likely mode of action. In the next part, I review the leading explanations.

Gender-bending: Leading Scientific Explanations for the Mode of Action

The mechanics of endocrine disruption are often described in the following way. Certain synthetic chemicals share structural features with common sex hormones; these chemicals, or xenoestrogens, mimic hormone action in the body by binding with, and activating, available hormone receptors. ${ }^{8}$ The endocrine systems of the body are understood as responsible for regulating complex and interconnected physiological processes, and thus synthetic chemicals that interfere with these systems are thought to have profound and wide-ranging effects on health. ${ }^{9}$ As hormones travel in the blood in very small concentrations, even very low levels of xenoestrogens can disrupt the flow of internal communications, triggering biological responses and functions in the processes of embryonic growth and development. Accordingly, susceptibility to xenoestrogens is thought to depend highly on sex and on the timing of exposures.

Several researchers feel strongly that a study of males could yield the most insight into the lowered sex ratio as there is a widespread acknowledgment of a general deterioration of male reproductive health worldwide, and many believe this can be traced to endocrine disruptors such as synthetic estrogens in the environment (Mostafa et al. 2007). These researchers contend that the father's exposure level is the best predictor of sex of the offspring (Mitchell 2004). When it comes to linking fathers to lowered sex ratios, the key variable seems to be sperm quality. Compromised sperm could be linked to decreased sex ratio, according to the theory, because altered paternal hormone levels might affect the viability of Y-bearing sperm or the foetuses conceived by them (Chilton et al. 2007).

In stark contrast to these researchers, others unequivocally link lowered sex ratios to 
mothers, with no mention of the possible role of fathers (Barker 2008). According to them, the link between endocrine disruptors, mothers, and skewed sex ratios is this: findings show that in communities with low sex ratios (here they studied Greenland and other communities in the far North) there are also elevated levels of hormonemimicking endocrine disruptors in the blood of pregnant women.

To understand why communities in the far north and a community in Sarnia, Ontario might both be disproportionately affected by endocrine-disrupting chemicals, it is essential to grasp the concept of bioaccumulation as it applies to the movement of persistent organic pollutants (a category to which most endocrine disruptors belong). Experts say that exposures to these chemicals will be highest at two locations: in very close proximity to the industrial sources and at the poles (very far from those industrial sources) (Howden 2007). According to the theory of bioaccumulation (on which an international treaty, the Stockholm Convention, ${ }^{10}$ is based), persistent organic pollutants get into air and water currents and eventually concentrate in the fatty tissues of those mammals at the top of the food chain. Arctic marine food chains are long, and resident mammals tend to have high amounts of fatty tissues in order to withstand the cold. At the top of many arctic marine food chains are those humans who consume seal, whale and fish as part of a traditional diet. In the late 1980s, this theory was found to be a very compelling explanation for why researchers sampling the contaminant levels in the breast milk of Inuit women found, not the low levels of industrial pollutants such as polychlorinated bi-phenols (PCBs) that they expected, but alarmingly high levels of such contaminants (Brown 2007).

Thus, the specific locations of communities with documented decreases in sex ratios (in Sarnia, and in the Canadian far North and Greenland), gives researchers further confidence in suggesting that perhaps the sex ratio decreases are attributable, at least in part, to the high levels of endocrine disrupting chemicals found in the blood of pregnant women. Perhaps, they suggest, this is because of the developing male 
embryos' dependence on the presence of certain key hormones being present at certain key times in the very early stages of development.

Finally, lurking in the shadows of all of this controversy is the emerging theory of 'feminisation' (Mittelstaedt 2008). This posits that there might be an in utero feminisation of embryos that could have been male. The idea is that we are experiencing, not just in humans but also in animal species throughout the industrialised world, a feminisation trend that is observable across a variety of markers including decreased sperm counts, increasing testicular cancers, declining levels of testosterone, and high incidence of undescended testes. "' "These things theoretically have a common etiology", according to Dr. Devra Davis (quoted in Mittelstaedt 2008). It is hypothesised that a declining sex ratio may be just one of a number of manifestations of a feminisation trend that is tied to endocrine disruption as very broadly experienced across the industrialised world.

Whatever the mechanism for the skewed sex ratio, it is still expectant mothers who seem to bear the brunt of the anxiety around pollution and exposures. This is as feminist theory would predict. As Margrit Shildrick (1997) contends, because reproductive potential and capacity have been signified as female, women (individually) bear the responsibility and guilt of failed attempts to reproduce; and, in this context (collectively), of a failure to produce babies of the expected gender in the appropriate proportions. Further, according to Anne Balsamo, "as a potentially 'maternal body', even when not pregnant, the female body is evaluated in terms of its physiological and moral status as a future container for the embryo or fetus"' (1996, p. 90). The pregnant woman thus comes to figure as an icon in the gendered environmental health movement, "born of the idea that the maternal body is responsible for the production of human and social nature, properly governed by normative laws of nature, and easily corrupted and interrupted" (Kukla 2005, p. 85). In Aamjiwnaang, these young mothers have a sense that something is interfering with their reproduction, and the normal or 
natural course of events as they should unfold. Something has invaded what should be a very intimate and private space. ${ }^{12}$ Sandra Steingraber, feminist ecologist and author, writes in 'We All Live

Downwind' that the experience of contamination "alters one's physical and sexual self and is thus a gendered experience which requires a feminist analysis" (1991,

p. 38). In this view, female anatomy has much to do with the construction of a woman's identity — and an 'altered' anatomy is an altered identity. But aboriginal women activists and authors such as Joni Adamson and Patricia Monture offer a retort to Steingraber's unifying rallying call to women: actually, they say, 'Some of Us Live More Downwind than Others'. The racialised nature of pollution, its distribution and its attendant environmental health harms is a key focus of environmental justice organising. Where responsibility for pregnancy is laid upon the mother alone, this gendered burden becomes individualised, privatised and removed from the political, economic and historical analysis.

And why should the pregnant body act as the repository for all our cultural hopes, dreams and fears? Why should the sex ratio issue garner so much attention when the actual suffering and poor health of livings beings-women, men and childrenattracts only indifference and dismissal? This brings us back to the glaring unfairness of the pollution's disproportionate impact on the native community in the context of their colonial history. In fact, understanding why the declining sex ratio might be showing up on the Aamjiwnaang reserve and not in 'white' Sarnia goes a long way to re-centring the role of land, capital, race and colonisation. The Aanishinaabek people have occupied their lands at the southernmost tip of Lake Huron for hundreds of years. As band member Ron Plain will tell you, on the Aamjiwnaang burial grounds,

you will find the remains of four generations of his ancestors, all in one place, literally on the fenceline of a large refinery: "we all lived here-all our lives". ${ }^{13}$ The permanence of both the pollution and of the Aamjiwnaang First Nation on the 
landscape, offers a possible explanation for why we might see a disproportionate effect of chronic pollution on this community: they are grounded both spatially and historically. If the mechanism behind the decline in sex ratio has a generational component, it makes sense that it would emerge in the First Nation community first. In south Sarnia, for example, which might experience comparable exposures to airborne pollutants, you are likely to find people who were born all over the country, if not the world. On the Aamjiwnaang reserve, you will not. It is a stark reminder of how contemporary pollution exists in social contexts that can exacerbate its effects.

\section{Collective Harm}

The impact of the pollution on the Aamjiwnaang people is imposed not only on individual bodies, of course, but on the community as a whole. In fact, it is through the work of feminist legal scholars towards exposing the nature of gendered harm that we have come to clearly understand that "injury has a social as well as an individual dimension” (Conaghan 1996, p. 408; Howe 1991; Conaghan 2002; Conaghan and Mansell 1993; Bender 1990). As Joanne Conaghan states, a person's membership in a "particular class, group, race or gender can significantly shape the nature and degree of harm they sustain" (1996, p. 408). It is in this vein that I turn next to the notion of a 'collective harm' in the hopes that it can better capture the wounds flowing from the sex ratio skewing on the Aamjiwnaang reserve. As one band member has stated: "our daughters will have to go outside our community for their partners". ${ }^{14}$ The concern is essentially one about cultural survival. It is the collective loss of a viable future. Thus the notion of a collective harm highlights the fact that this problem is situated in the context of an aboriginal community already struggling, as many are, with stemming the loss of culture and tradition amongst their people.

“Injury”, as David Engels argues, “opens a window onto identity” (2000, p. 3). This 
is because "[w]hen we say that an individual has suffered an injury, we implicitly refer to a self that is constituted in a particular way and is therefore vulnerable to particular kinds of harm" (Engels 2000, p. 3). It is the specific history of the Aamjiwnaang First Nation which makes the community, as a whole, particularly vulnerable to pollution harm. As Robert Verchick makes clear:

localised environmental hazards do not simply harm individuals, they erode family ties and community relationships...[they] create community-wide stress that will debilitate the neighborhood in emotional, sociological, and economic ways. To ignore this communal harm is to underestimate severely the true risk involved. (1996, p. 84)

Further, following Verchick, because emerging environmental health harms are often localised and concentrated, and because they tend to be distributed along race and class differentials, the wound to the affected community, in this case the Aamjiwnaang First Nation, takes on a "profound moral character" (1996, p. 84). Just as Native Americans have characterised the US military's poisoning of Indian land as genocide, so the charge of cultural extermination has been leveled by residents in the case of Aamjiwnaang with respect to the slow poisoning of their people and their traditional territory. In this way, the theory of endocrine disruption in the context of a First Nation encounters a history that has, at various times, refused racialised groups the capacity for children. Is forced sterilisation - the "racist form of mass 'birth control'" described by Angela Davis (2008, p. 86) as it has applied historically to poor black women in the American context - any different from what is happening today on the Aamjiwnaang reserve? Class bias and racism, as Davis (2008) notes, has always contributed to how we, collectively, figure out who may legitimately contribute to the next generation, to the 'future'. ${ }^{15}$ A parallel could be drawn between historical practices of eugenics in which outsiders decided on behalf of women, and their communities, 
whose lives would be worth living and whose children would be welcome in this world (Hubbard 1997), and the current political economy of pollution in Canada. Perhaps our attitudes towards the evidence of endocrine disruption and its role in the ability of the Aamjiwnaang First Nation to replace itself is based on a "cluster of unexamined and unspoken preconceptions about who should and who should not inhabit the world"' (Tremain 2002, p. 481). Is the lack of public outcry merely a reverberation of Canada's own genocidal past? Is it cultural extermination by a new mechanism?

Searching for an injury in law, in this situation, is futile. There is wounding to be accounted for, surely, but it is not the kind of harm that can be captured by our current legal imaginary. Contemporary pollution harms are diffuse, body-altering, cumulative, and probably generational in character. In this case, the pollution manifests in a way that challenges us to integrate social, biological and cultural aspects of community life into colonial and petrochemical legacies. And further, as I will demonstrate in the next section, conceptualising the wound suffered by the Aamjiwnaang (at least in terms of the declining sex ratio) as a harm at all, demands allegiance to notions of what is 'natural' and what is 'normal' that fly in the face of developments in sex and gender theory.

\section{Theorising Sex and Gender}

Conventional wisdom holds that sexual identity occurs 'naturally' as a binary category, which consists of two 'opposite' sexes: male and female (Bloom 2009). That there are only two mutually exclusive categories is not questioned in the environmental health movement. But as the growing literature on intersexuality makes clear, "many bodies, even in 'nature', simply do not fit very well into the rigid boundaries of a

male/female classification" (Bloom 2009, p. 3). Conservative estimates put the 
incidence of intersexuality at around 1 in 2000 births, with as many as 1 in 100 of us born with bodies 'differing' from the standard traits of male or female. As Jennifer Nye (1998) argued in The Gender Box, it may be better to think of a continuum of sexes with people distributed across a spectrum.

But, many will protest, surely genetics settles the matter conclusively: it is the presence or absence of the Y chromosome that creates a binary. Students of introductory biology courses may recall a standard narrative something along these lines: A person's sex is predetermined in the sperm gamete. The cells of the egg gamete all possess the $X X$ sex chromosomes. Around half of the sperm gametes contain the $X$ chromosome and others possess the $Y$ chromosome. In light of this, there are two possibilities that can occur during fertilisation between male and female gametes, $X X$ and $X Y$. Since sperm are the variable factor, they are responsible for determining sex.

In life, it turns out, it is more complicated. In some cases, babies are born with an extra $\mathrm{X}$ or an extra Y, and some babies are born with only one $\mathrm{X}$ (Bloom 2009). In many more cases, babies are born with, or individuals develop later in their life, physical traits that do not comport with the category designated to them. For example, some $\mathrm{XX}$ individuals have both ovaries and the reproductive equipment we might typically associate with a male. And in many more cases still, individuals exhibit personality traits or gender identities that put them on a collision course with prevailing cultural expectations about the characteristics that are typically associated with the two categories of sex identity. If this all seems new, it is because, as Anne Bloom demonstrates beautifully, several authoritative discourses and institutions (law and medicine chief among them) have "collaborated" so as "to make binary sexual difference appear more 'natural' than it is"' $(2009$, p. 3).

Hormones, of course, are implicated as well. According to the standard line, sex is determined by genetic factors, and sexual differentiation is driven by hormones. As Nelly Oudshoorn's (1994) work exposes, the 'discovery' of hormones early in the 
twentieth century became celebrated as providing the "missing link" between genetic and physiological models of sex determination. It quickly became accepted that the "intentions of genes must always be carried through by appropriate hormones" (Oudshoorn 1994, p. 20). Accordingly, hormones assumed the role of the "chemical messengers" of masculinity and femininity. ${ }^{16}$

\section{Constituting Polluted Bodies}

I turn now to the idea of gendering. Following Dorothy E Chunn and Dany Lacombe, who argue that "law as a gendering practice" pays heed to the "diverse and contradictory ways that law constrains and enables-i.e. constructs-womanhood" (2000, p. 16), my examination of the theory of endocrine disruption seeks to explore how the pollution constrains, enables and constructs, literally, at a molecular level, the gender of bodies. Anne Bloom sums up the feminist orthodoxy as follows:

sex, as it is typically understood in both cultural and legal narratives, refers to a stable and pre-cultural biological reality that may be assessed and verified through a visual assessment. Gender, in contrast, tends to be defined in more socially contingent terms. (2009, p. 9)

Law, in this understanding, might act on gender, but it takes biology as a given. Law takes bodies as it finds them. But if pollution is capable of altering the very make-up of the human body, and law 'produces', or at the very least 'tolerates' these chronic, lowdose exposures, then law is acting on bodies - on the material, physical, biological reality of bodies.

According to feminist theorist of the body Elizabeth Grosz:

The body has thus far remained colonized through the discursive practices of the natural sciences, particularly the discourses of biology and medicine. It has 
generally remained mired in presumptions regarding its naturalness, its fundamentally biological and precultural status, its immunity to cultural, social, and historical factors, its brute status as given, unchangeable, inert, and passive, manipulable under scientifically regulated conditions. (1994, p. x)

But the "ways in which bodies, men's and women's bodies, are understood by the natural sciences", she tells us, is "no more accurate than the ways the social sciences and humanities understand them" (1994, p. x). Thus it is not just gender that is constructed, it is sex as well, and further, in Grosz's analysis, the forces shaping that construction are the forces that govern the relations between the sexes-the power relations. In this respect, Grosz seems to align with the emerging feminist orthodoxy of sex and gender as described above. She allows that:

bodies cannot be adequately understood as ahistorical, precultural, or natural objects in any simple way; they are not only inscribed, marked, engraved, by social pressures external to them, but are the products, the direct effects, of the very social constitution of nature itself. (1994, p. x, my emphasis)

Bodies, she continues, betray an "organic openness to cultural completion...they must take the social order as their productive nucleus"' (1994, p. x).

But Grosz's position diverges in a key respect. ${ }^{17}$ In her analysis, bodies must also be reducible to a basic materiality. Sexual difference cannot merely be a "matter of the inscription and codification of somehow uncoded, absolutely raw material, as if the materials exert no resistance or recalcitrance to the processes of cultural inscription" (1994, p. 190). To return to the Aamjiwnaang example, law, if it is here producing gender, is not only inscribing and coding some blank biological slate, but it is altering that material reality. It is not just 'culturally completing' bodies, but participating in their very constitution. If bodies take the social order as their productive nucleus, these bodies take that order to be one in which pollution and contamination are deeply 
embedded and risk is part of the landscape.

Often, according to Grosz, "[b]odies provide a neuralgic locus for the projection and living out of unreflective presumptions regarding the sexes and their different social, sexual and biological roles" (1994, p. x). In contemporary environmental justice organising, our awareness of the complex nature of pollution, and of the mechanisms of endocrine disruption, brings the body into focus and exposes the active construction and categorisation of bodies into discrete sexes. Still, if there is no 'natural' categorisation of sexual identity as a binary, perhaps there is no 'normal' balance between two discrete sexes. ${ }^{18}$ Without these critical assumptions in place, how can we characterise the declining sex ratio of the Aamjiwnaang community as a harm? If not through recourse to what is 'natural', on what basis can we determine that endocrine disruption, or pollution, in any case, is harmful? Can we say that uninvited changes to bodies are unwelcome? That just as 'risks', however rational to incur at a societal level, are unacceptable if they are imposed involuntarily or if they result in the unfair sharing of benefits and burdens (Scott 2008), so the loss of chance in this case is unacceptable?

The answer must be that we validate the harms of the pollution that are tied to illness and suffering and not those that signify difference. Those harmed by the pollution are the people living in Aamjiwnaang-they are the women, men and children, mostly girls, but nevertheless the children of the Band. They are:

the young aboriginal mothers, they are parents who routinely receive "emergency alerts" over the radio indicating that they should "Shelter in Place" as a result of an incident or a "fugitive release" from neighboring industry, they are daycare workers responding to the sirens by shuffling toddlers inside and closing the vents, they are health clinic staff staring down bewildering statistics, they are teenagers struggling with asthma, developmental and attention-deficit disorders, and they are young children prevented from swimming 
in the contaminated creek that passes through their traditional powwow grounds.

(Scott 2008, p. 311)

These are the people living with the effects of the chronic exposures to pollution that emanate from Sarnia's Chemical Valley. The community has more than its fair share of illness and suffering: $17 \%$ of adults and $22 \%$ of children surveyed have asthma; about $25 \%$ of adults experience high blood pressure and/or chronic headaches; about $25 \%$ of children suffer from learning disabilities and behavioural problems; and about $40 \%$ of women have experienced miscarriage or stillbirth. ${ }^{19}$

The depiction of endocrine disruption and the declining sex ratio of the Aamjiwnaang First Nation deployed by the environmental justice movement-its characterisation as a dramatic, new and horrifying harm-demonstrates what Jain calls "the peril of politics in the sentimental mode" (Jain 2007, p. 520). The women's environmental health movement trades heavily on the image of the pregnant mother and her foetus as the symbol of our future. The environmental justice movement, in most attempts to draw in gender as a locus of organising, adopts the same approach. But the discourse, from a critical, embodied and decolonising perspective, leaves much to be explored (Smith 1999).

An 'embodied' approach is one that seeks to capture the material and historical specificity of the human form. At the same time, it does not imply some "unified and singular bodily form of the male and the female" but instead draws attention to the universal human condition of being 'in' our bodies (Mellor 1997, p. 9). Human embodiment spans all sorts of biological imperatives: from hunger and excretion to aging and dying. It also includes change through various life stages driven by hormonal cycles. These cycles create windows of vulnerability that have a distinct biological and thus gendered nature (Krupp 2000). It is here that estrogens take on a pivotal role, and the role of xenoestrogens, in particular, becomes salient. When synthetic chemicals, uninvited, take over for hormones, binding with available 
receptors and orchestrating physiological processes, it has real, tangible, material consequences for bodies. When this happens in the context of reproduction, it has gendering consequences.

It seems that the horror associated with the theory of 'feminisation' as a manifestation of underlying endocrine disruption must be tied to its potential for completely disrupting the 'heterosexual matrix', as Butler terms it (1993). This is so, it seems, because the theory of feminisation inherently must take a pre-cultural notion as the standard for human physiology. It presumes a baseline of normalcy in order to project its feminising trend. The heterosexual matrix is "that grid of cultural intelligibility through which bodies, genders and desires are naturalised" (Tremain 2002, p. 459). Ironically, the phenomenon of endocrine disruption actually has the potential to accomplish the feminist project set out by Butler-the proliferation of non-coherent genders (1993) — not intentionally, as she envisions with the goal of exploding the heterosexual matrix, not in any counter-hegemonic way, but insidiously and completely governed according to the hegemonic economic relations that facilitate the production of pollution and the consumption of chemicals.

Acknowledging that the horror that greets the feminisation hypothesis derives, at least in part, from a heteronormative stance invites us to consider Grosz's call for 'openness' (2005). Any attempt to identify a trend as 'unnatural', whether in terms of a sex ratio or just in terms of the parameters we purport to measure as markers of gender in support of a feminisation model, for example, depends on a static or fixed conception of bodies, nature and the human form. The idea that ontology is "indifferent to history, particularity or change-require[s] transformation and revitalization", according to Grosz (2005, p. 5). The materiality of 'being', itself, must be opened up to its "becomings, to the temporal forces of endless change, in other words, to biology, culture, sexuality" (Grosz 2005, p. 5). Thus, culture, in Grosz's conception, is not the "completion of nature, its culmination or end, but can 
be seen as the ramifying product and effect of a nature that is ever-prodigious in its techniques of production and selection, and whose scope is capable of infinite and unexpected expansion" (2005, p. 31, my emphasis).

On my reading of Grosz, her theory of 'becoming' translates into a call for tolerance and openness to a changing human form. ${ }^{20}$ It asks us to question our tendency to resist the intermingling of history and biology; to embrace dynamic and open-ended understandings of the body, and to surrender to the indeterminable direction and fluidity of bodily forms. As such, Grosz's theory of 'becoming' affirms both the irreversibility of time, and the centrality of chance. But here, in the context of endocrine disruption on an aboriginal reserve, it is dissatisfying in its attitude of indifference because it seems to erase the blameworthiness of the ongoing pollution.

\section{'Becoming' Polluted}

Why should we open the materiality of being to 'becoming'? What do we gain from turning to Grosz in this instance? Or, as Judith Butler (1993) has asked, what does it mean to have recourse to materiality? What we gain, in my view, is a cogent challenge to the modern subject as a disembodied, unitary being. Implicit in Grosz's theory of 'becoming' is a Deleuzian conception of the body, which does not rely on an individuated subject, but calls for a "morphing of the body into a site of patterns, flows and intensities in which the emphasis is continually on movement" (Bottomley 2002, p. 140). Thus, here, where the injury is not cognisable to law on an individual level, but the harm or the wounding is present along many dimensions and is obvious in a collective sense, Grosz provides an antidote to the individualised ideal of the liberal, monadic legal subject. She understands the body "not as an organism or entity in itself, but as a system, or a series of open-ended systems, functioning within other huge systems it 
cannot control" (2004, p. 3). This is useful because it places the Aamjiwnaang people as subjects immersed in a social, political and historical context that accentuates their vulnerabilities to the pollution - to the intensities and flows operating at a molecular level, to the energies and connections between synthetic hormones and available receptors within bodies.

Further, the suspected generational effect of the pollution draws on Grosz's idea that we come from not only a specific body, but a "chain of bodies...a genealogical and maternal element" (2004, p. 2). "As living beings", she states, "we are the accumulation and concretion of our history, of what has happened to us and what we have done, perhaps even before our personal or subjective existence' (2004, p. 196). Our own pasts, the pasts of our parents, even our cultural histories are carried within each of us. ${ }^{21}$ The past is persistently in the present; its constituent bits, present at the level of molecules, are rearranged and reconfigured in ourselves.

The declining sex ratio emerges as an eruption of unpredictability in a material world that is otherwise tightly structured by forces external to the Band. Where the subjects of pollution are not easily conceptualised as individual, liberal, monadic entities, but are instead understood as embedded in cultural histories, in a community, tied to the land, and inseparable from local intensities and flows, emitted particles, energies and connections operating on a molecular level, we need this theory to adequately understand the Band as embedded in wider ecologies. We need to pay attention to material systems in their "complex interlocking totality" (Grosz 2004, p. 198).

The failure of tort law to provide a remedy to the Aamjiwnaang community derives from its underlying assumption that "society is composed of free, separate, autonomous individuals, competing with each other in pursuit of their own selfinterest" (Conaghan 1996, p. 408). Robin West, as noted above, has challenged the notion of 'separateness' for women based on her 'connection thesis', foregrounding our 
potential for reproduction, and scholars working on foetal microchimerism, such as Aryn Martin, demonstrate that the maternal body is "irretrievably transformed by the experience of pregnancy" (2009, p. 8). The boundaries of women's individuality are permanently confused by the fluid movement of cells that occurs between a mother and her foetus. But Grosz's analysis takes the challenge much deeper. Not only can women not be conceived of as 'separate' from other life, but men cannot either. All living things are embedded and interwoven into larger webs of being. So, tort law is conceptually inadequate to our task primarily because it "individualises what is essentially a group wrong" (Conaghan 1996, p. 430), discounting the role of power, entrenched interests, and the state in the perpetuation of the pollution. ${ }^{22}$

Grosz's perspective exposes our inability to imagine law differently. Why is the individual person the appropriate unit or level of analysis for assessing damages in tort law? Why not assess it at the level of communities? Or conversely, at the molecular level? At the level of cells? Legal scholars have begun exploring the idea that tort law is too corporeal-that it is tethered too tightly to proof of physical damages - and should move towards the recognition of 'interests-based' damage assessments in specific contexts (Nolan 2007; Witting 2002, 2008). But even where recent scholarship in tort has included some calls for expansion of what should count as harm or 'physical damage' (Witting 2002, 2008; Nolan 2007; Priaulx 2004), the scale at which we look to find such damage remains at the level of the individual, the single, unitary legal subject. Witting says we should move away from assessing physical damage only on the basis of a "factually observable" change in the physical structure of persons, and advocates for a more contextual approach based on social perceptions of damage (2002, p. 190). As Nolan says, "the boundaries of the concept of physical damage are not always clear" (2007, p. 61) and clearly might be expanded. This goes some way towards opening up the question of what constitutes harm, but leaves unexplored, for now, the matter of the appropriate scale on which we 
should measure it.

Grosz takes seriously how "the biological prefigures and makes possible the various permutations of life that constitute natural, social and cultural existence" (2004, p. 1). Her work validates the "messy, complicated, resistant, brute world of materiality" (2004, p. 2), on which pollutants operate, internally modifying bodies, triggering biological functions, assembling and reassembling pieces on a molecular scale. Thus, if we want to understand not just how culture inscribes bodies, but how pollution itself inscribes bodies, we need a corporeal feminism, a theory that foregrounds our basic materiality.

Finally, the theory of 'becoming' has relevance also for illuminating the political dimensions of struggle. In aiming to expose the effect of time on the organisation of matter, it demonstrates how both biology and politics are inevitably reconfigured by temporality. Accordingly, 'becoming' is also about the production of conceivable futures: "the future understood as that which is not similarly contained in the present, but rather, as what diverges from the present, as what produces a new future, one uncontained by and unpredicted from within the present" (Grosz 2004, p. 255).

Directions, Flows, Futures

The dual strategy of environmental justice activists worldwide - of both accumulating scientific allies to form credible technical arguments and also continuing to confront industry and government with "the faces of real people who are being harmed" (Verchick 1996, p. 48) —is complicated, but not completely dislodged, by the question of endocrine disruption and declining sex ratios. Those activists have employed the faces of the Aamjiwnaang people, the faces of young girls, in a genuine and legitimate 
attempt to draw attention to their struggle and bring redress to their situation. This is in recognition, perhaps, of the fact that the endocrine disruption, while it is not the primary source of suffering on reserve, has the potential to focus attention on the problem to an extent that had not been possible prior to its being made visible. Aboriginal activists from the reserve itself have played key roles in the mobilisation of this resistance movement.

The main task for the movement going forward, as I see it, is to expose the political economy of pollution: to question who benefits from and who pays the price for the continued release of endocrine-disrupting chemicals into the environment. It is to bring back into focus the role of capital, land use, colonisation, race and the state in our examination of bodies and how they are changing in the context of contemporary pollution. We need to watch, as Jain says, "the ways in which gender is constituted and inhabited in relation to industrial capitalism and the distribution of... its modes of suffering"' (2007, p. 506).

Why should we try, as law does, to disentangle the 'harm' from the social and economic conditions (racism, capitalism, colonialism) that enable the pollution in the first place? When we turn to tort law to remedy the harms of endocrine disruption, it tells us to examine and explain every spill, every discharge of endocrine-disrupting chemicals, and every injury individually, as an anomaly to the normal course of events. Tort law is an expression of the "liberal preference for non-intervention by the state into social arrangements" (Conaghan 1996, p. 408). It offers a private law solution, between individuals; it is blind to the public dimensions of the problem and the way that state law, through the regulatory design, shapes the behaviour of key actors, notably in this case, polluters.

While law's treatment of chronic pollution harms, through the tort system, understands and approaches each wound as an avoidable side-effect of our 'advanced' industrial economy — which can sometimes be translated into a legal injury deserving 
of compensation-it misses the very centrality of wounding to contemporary capitalism. Once profound human wounding, through chronic exposures to toxic chemicals, is understood as a central, foreseeable consequence of the production process, the underlying basis of tort law-that it applies to compensate for injuries that result from 'accidents' and 'side effects'-becomes unsustainable. The effect of law's treatment of pollution as exceptional, and the inequality of the distribution of that pollution, is rendered visible.

In law, for a corporation, or collectively, an industry, to be held accountable or responsible for a given 'wound', we require that wound to translate into a legally recognisable 'injury'. The plaintiff's task is to show how the consequences of law's indifference have been visited on specific real people and not on statistical futures. It is to put agency back into regulatory design. Injury, as Jain puts it, "provides a moment of disjuncture...it potentially threatens, in the most radical way, the entire basis of economic rhetoric that insists that production and consumption take place in the interests of a common social good" (2006, p. 12). If this rhetoric is accepted, then the logic proceeds to demand a mechanism for determining and distributing compensation to those accidentally harmed. Jain calls this the "trope of compensation"' (2006, p. 12). It is based on the idea of reparable harm. Within the trope, the legal logic demands that the injury be made calculable in market terms, so that the injury can be 'undone' through the monetary award of damages, and the injured can 'buy back' what was lost. 'Recovery', in law, is meant to restore, repair or compensate a victim as a matter of justice. It aims to return the injured person to the condition she would have been in had the injury not occurred. The prospect of recovery for the Aamjiwnaang community is what makes it very clear that the wound, in this case, is much deeper than the injury-the wound will never be closed by an award of damages (even if any were forthcoming).

Scholars have made considerable inroads at the task of harnessing the power of tort 
law for social justice (Bender 1989, 1998). Leslie Bender says that it is a myth that money damages is all our legal system can offer in terms of compensation or reparation. She sees tort law in the coming century as a "tool for social equality and justice struggle, rather than as a purely compensatory mechanism" (1998, p. 249). She believes that we will come to recognise as damage those harms to dignity that are "imposed by a social order that seems to permit people to conduct themselves in ways that injure others for their own benefit or in promoting their own interests" (1998, p. 251). The task is only to imagine creative new remedies that can work to restore dignity and social equality, and remedies that acknowledge collective harms based on the interconnectedness of life (1989, p. 870).

Imagining and claiming these remedies is a task for environmental justice activists and organisers worldwide. Further, in recognising law's role in the perpetuation of pollution on the landscape and in the continuous circulation of endocrine disruptors in environments and in bodies, we need to be more specific about the actual and multiple processes, institutions and actors that constitute, shape and implement 'law'. Strategies and ways forward in the task of exposing the political economy of pollution will need to isolate and attack particular regulatory rules and administrative regimes operating in multiple jurisdictions. Much of the conceptual work has been started (Bullard 1993, 2005; Cole and Foster 2001; Brown 2007) and some grassroots organising and training is also gaining momentum (see, for example, Global Community Monitor 2006).

\section{Conclusion}

The challenge coming for feminist environmental health activists is to take account of the significance of biological differences between bodies without taking those 
differences to be natural, or 'pre-cultural'. ${ }^{23}$ In the context of this particular problem, that of endocrine disruption, we have to delve deeper than the familiar 'socialisation' analysis, which explains that pollution affects women differently than men because women's roles in the environment, in the home, in the workplace, differ from men's. This is, of course, still true, but is only part of the story. Following Bottomley (2002), if it consumes our focus we will miss the opportunity to do some serious and important thinking about the biological - the material-aspects of this dynamic that are distinctly raised by emerging research. ${ }^{24}$ As feminists, we have resisted, with good reason, discourses that draw their authority from claims to 'naturalism'. ${ }^{25}$ And accordingly, we tread with some hesitation: a focus on materiality undoubtedly raises complex questions and tensions, but it might capture, at a key juncture, that there is a more complete story to be told about why a focus on gender and environmental health matters: contaminants act on bodies, and bodies are sexed.

The discourses around endocrine disruption employed by the environmental justice movement are clearly motivated by the desire to "ground or to verify a set of injuries or violations" (Butler 1993, p. 29) deriving from a sense, which I share, that the pollution and the wounds flowing from it are blameworthy and must be mitigated. I began this paper with the aim of exploring how the work of feminist theorists of the body and the study of environmental law and justice might be combined so as to reveal the complex nature of contemporary pollution harms. Why should we look to the Aamjiwnaang situation as an emblem of contemporary pollution problems? The Aamjiwnaang case captures the essence of contemporary pollution, in my view, for a number of reasons, none of which foreground the declining sex ratio or the 'feminisation' of the species, or the claim that humanity is at risk. Those reasons are: the harms are pervasive, diffuse, and body-altering; the links between those harms and the suspected chemical culprits are tenuous and contested; and further, the harms are not randomly distributed, or uniformly experienced. Thus, by interrogating the 
gendered and the gendering effect of the chronic pollution, we might better understand the nature of contemporary pollution harms, and we might re-imagine our strategies as advocates in the environmental justice movement so as to find harm where there is illness and suffering, but not simply where there is difference. As demonstrated, it is not difficult to find illness and suffering on the Aamjiwnaang reserve. The 'wounding', the sex ratio skewing, just brings the problem into focus.

But tort law in its current form falls short of capturing the essence of this pollution because, in transforming it into a form cognisable by law, we are forced to locate the harm in separate, autonomous individuals. At the same time, activists in the environmental justice movement tend to lock onto the "gender-bending" aspects of the harm. But following the line of analysis that has not just gender but also sex as socially and culturally constructed, fails to give effect to the embodied reality of living with chronic pollution. It fails to recognise that bodies are reducible to a basic materiality, and therefore it discounts the real and material consequences, the gendering consequences, that synthetic chemicals are having within bodies. Yet even on an embodied analysis, finding harm in endocrine disruption and a declining sex ratio depends on a static or fixed conception of bodies, nature and the human form. Here, Grosz's theory of 'becoming' calls for more tolerance: openness to an indeterminable direction for bodies allows us to see that we should find harm where we find illness and suffering, but not simply where we find difference. At the same time, the theory of 'becoming' also invites us to open up our political projects to new directions and orientations, "not inconsistent with various struggles for rights and equalities, but moving beyond them: an indeterminable direction, beyond planning and control in the present...always in the process of transformation' (Grosz 2005, p. 5). It opens up feminist environmental justice organising to the challenge of exposing the blameworthiness of the pollution. It returns the focus to the political, economic and historical conditions under which "gender-benders" are perpetually circulating on the Aamjiwnaang First 
Nation reserve, and the way that law is implicated in their continued presence.

Acknowledgments This paper has been in the works for a long time. I was inspired initially by an invitation from Mary Jane Mossman, Director of the Institute for Feminist Legal Studies at Osgoode Hall Law School, to present some of my empirical findings from my study of environmental health and the Aamjiwnaang First Nation at one of her trademark Feminist Fridays events in Fall 2007. Since then, too many people to name have contributed. I benefited tremendously from a workshop entitled Critical Perspectives on Environment and Women's Health, held in Toronto on 29 January 2009 and sponsored by the National Network on Environments and Women's Health. I would like to thank all participants, but this work has been influenced most through productive exchanges with Anne Bloom, Sarah Lochlann Jain and Stu Marvel. My friends and colleagues Roxanne Mykitiuk and Ruth Buchanan agreed to read Grosz with me, and despite the fact that life intervened and we didn't actually get together on that patio over wine to discuss her work last summer, I am still indebted to them for agreeing. If they hadn't, I would have continued to push these books to the side. My partner Adrian Smith, as always, was my most insightful and creative critic. Funding for the research has been provided by the Social Sciences and Humanities Research Council of Canada. 


\section{Notes}

${ }^{1}$ Ada Lockridge, Health and Environment Committee Chair, Aamjiwnaang First Nation, personal communication, 26 March 2008.

${ }^{2}$ Community member comments to the Aaamjiwnaang Environmental Health Symposium, Sarnia, Ontario, 27 March 2008: notes on file with author.

3 The regulation in effect in Sarnia is Air Pollution-Local Air Quality O. Reg. 419/05 under the Ontario Environmental Protection Act, RSO 1990, c E19 [hereafter OEPA].

${ }^{4}$ In Ontario, it is the OEPA, ss 6(1) and 9(1).

${ }^{5}$ Interestingly, Nelly Oudshoorn, in her work on the social and historical conditions under which scientists 'discovered' hormones, states that advances in biomedical science "made the invisible visible" with respect to the action of hormones in the body (1994, p. 4).

${ }^{6}$ Ron Plain, 'Exposing Canada's toxic shame' event, lecture delivered at the Faculty of Environmental Studies, York University, 12 March 2008: notes on file with author.

${ }^{7}$ These strategies were shared with me by members of the Aamjiwnaang First Nation at the Aamjiwnaang Environmental Health Symposium, Sarnia, 26 March 2008: notes on file with author.

${ }^{8}$ The term "hormone-mimics" was made popular through the very influential 1997 book by Coleborne et al., Our Stolen Future, which is said to have done for endocrine disruption what Rachel Carson's Silent Spring (1962) did for pesticides, in terms of inspiring an environmental movement.

${ }^{9}$ For a description of the mechanics of endocrine disruption from the perspective of contemporary science, see Solomon and Schettler (2000). For a compelling account of how hormones emerged out of the historically and socially specific conditions of endocrine research environments in the early twentieth century, see Oudshoorn (1994). I am grateful to Mariana Valverde for putting me onto the critical work of Nelly Oudshorrn

${ }^{10}$ Stockholm Convention on Persistent Organic Pollutants, 22 May 2001, 40 ILM 532 (entered into force 17 May 2004).

${ }^{11}$ Langston (2008) also attributes rising "rates of intersexuality" to endocrine disruption.

${ }^{12}$ For work on tort law's treatment of injuries related to interference with a woman's control over her own reproduction, it is useful to consider the 'wrongful conception' suits that have arisen in situations where women sue their doctors for negligent sterilisation or contraception procedures. The challenge for tort law in these cases is, of course, the assessment of damages: a healthy child is born, and yet, a woman is claiming she has been wronged, her right not have an unplanned child has been infringed. Can we assign a 'harm' to the birth of a child? (see, e.g., Sheth 2006).

13 Plain, supra n 6.

14 Ibid.

${ }^{15}$ See also the work of Dorothy Roberts that exposes how the material conditions of poverty and oppression have limited the reproductive options and choices for poor women of colour who have been "deemed not even worthy of the dignity of childbearing" (1991, p. 1458).

${ }^{16}$ As Oudshoorn (1994) demonstrates, since the earliest writing on endocrinology in the early twentieth century, scientists labelled the hormones as 'female' or 'male'. Today scientists recognise that hormones do not belong to one sex or the other, and yet the labels persist because they serve as a form of cultural shorthand. Our understandings of endocrine disruption, predictably, invoke these binary categories in popular representations.

${ }^{17}$ In fact, both Grosz and Butler (1993) have endorsed a "corporeal" feminism.

${ }^{18}$ As Anne Bottomley has noted, these assumptions have been fundamental: "knowledge of ourselves and of our world, has been predicated upon binary constructs of...male/female" (2002, p. 127).

19 These data were presented by Sharilyn Johnston and Ron Plain at the Aamjiwnaang Environmental Health Symposium, Sarnia, Ontario, 27 March 2008: notes on file with author.

${ }^{20}$ This is also true of other feminist scholarship, e.g. Anne Bottomley has argued that with respect to its image, its use and its appearance, "there is an important sense in which the body morphs" (2002, p. 127).

${ }^{21}$ In Butler's words, "matter has a history (indeed, more than one)" (1993, p. 29).

${ }^{22}$ As Conaghan's work reveals, there is a parallel here to Catharine MacKinnon's groundbreaking analysis of tort law's impotence for remedying sexual harassment (1979).

23 "It is precisely because we are interested in the social, the cultural, the historical, and the political forces shaping subjectivity or identity that we need to turn again, with careful discernment, to those discourses, once rejected by feminists and political activists, that place the body in the larger cosmological and biological orders in which it always finds itself' (Grosz 2004, p. 3).

${ }^{24}$ As Bottomley urges, "we have to be willing to engage more directly with the corporeal, sexed and therefore differentiated, body rather than remain within the seemingly safer region of cultural 
representation, construction and encoding of gender' (2002, p. 144).

${ }^{25}$ For a fuller description of this dynamic within feminist legal scholarship, see Bottomley (2002, p. 129).

\section{References}

Balsamo, Anne Marie. 1996. Technologies of the gendered body: Reading cyborg women. Durham, NC: Duke University Press.

Barker, Elizabeth. 2008. A world without men. Whole Life Times, February. http://www.lime.com/ magazines?uri=wholelifetimes.com/lime/2008/02/healthyliving0802.html. Accessed 18 Sept 2009.

Bender, Leslie. 1990. Feminist (re)torts: Thoughts on the liability crisis, mass torts, power and responsibilities. Duke Law Journal 37: 848-912.

Bender, Leslie. 1998. Tort law's role as tool for social justice struggle. Washburn Law Journal 37: 249-260. Bloom, Anne. 2009. Sex, bodies, torts. Unpublished manuscript, on file with author.

Bottomley, Anne. 2002. The many appearances of the body in feminist scholarship. In Body lore and laws, ed. Andrew Bainham, Shelley Day Sclater, and Martin Richards, 127-148. Oxford: Hart Publishing. Brown, Paul.

2007. Man-made chemicals blamed as many more girls than boys are born in Arctic. The Guardian, 25, 12 September.

Bullard, Robert D. 1993. Confronting environmental racism: Voices from the grassroots. Boston: South End Press.

Bullard, Robert D. (ed.). 2005. The quest for environmental justice: Human rights and the politics of pollution. San Francisco: Sierra Club Books.

Butler, Judith. 1993. Bodies that matter: The discursive limits of sex. New York: Routledge. Carson,

Rachel. 1962. Silent spring. Boston: Houghton Mifflin.

Chamallas, Martha, and Linda K. Kerber. 1990. Women, mothers and the law of fright: A history. Michigan Law Review 88: 814-864.

Chilton, Janice, Rikuo Doi, Lovell Jones, Devra Davis Lee, Hillary Stainthorpe, and Pamela Webster. 2007. Declines in sex ratio at birth and fetal deaths in Japan, and in US Whites, but not African Americans. Environmental Health Perspectives 115: 941-946.

Chunn, Dorothy E., and Dany Lacombe. 2000. Introduction. In Law as a gendering practice, ed. Dorothy E. Chunn, and Dany Lacombe, 2-18. Don Mills, ON: Oxford University Press.

Colborne, Theo, Dianne Dumanoski, and John Peterson Myers. 1997. Our stolen future: Are we threatening our fertility, intelligence and survival? New York: Plume.

Cole, Luke W., and Sheila R. Foster. 2001. From the ground up: Environmental racism and the rise of the environmental justice movement. New York: NYU Press.

Colihan, Mary Ann. 2008. Chemical valley: Aamjiwnaang First Nation in Sarnia sounds alarm over toxins. CBC News In Depth. http://www.cbc.ca/news/background/aboriginals/health.html. Accessed 18 Sept 2009.

Conaghan, Joanne. 1996. Gendered harms and the law of tort: Remedying (sexual) harassment. Oxford Journal of Legal Studies 16: 407-431.

Conaghan, Joanne. 2002. Law, harm and redress: A feminist perspective. Legal Studies 22: 319-339.

Conaghan, Joanne, and Wade Mansell. 1993. The wrongs of tort. London: Pluto Press.

Cranor, Carl. 2006. Toxic torts: Science, law and the possibility of justice. New York: Cambridge University Press.

Davis, Angela. 2008. Racism, birth control and reproductive rights. In The reproductive rights reader: Law, medicine, and the construction of motherhood, ed. Nancy Ehrenreich, 86-93. New York: NYU Press.

Engels, David. 2000. Injury and identity: The damaged self in three cultures. In Between law and culture: Relocating legal studies, ed. Lisa C. Bower, David Theo Goldberg, and Michael Musheno, 3-21. Minneapolis, MN: University of Minnesota Press.

Erikson, Kai. 1991. A new species of trouble. In Communities at risk: Collective responses to technological hazards, ed. Stephen R. Couch, and J.Stephen Kroll Smith, 11-30. Peter Lang: New York.

Global Community Monitor. 2006. History of the bucket brigade. http://www.bucketbrigade.net/article. php?list=type\&type=74. Accessed 18 Sept. 2009.

Grosz, Elizabeth. 1994. Volatile bodies: Towards a corporeal feminism. Bloomington, IN: Indiana University Press.

Grosz, Elizabeth. 2004. The nick of time: Politics, evolution and the untimely. Durham, NC: Duke University Press.

Grosz, Elizabeth. 2005. Time travels: Feminism, nature, power. Durham, NC: Duke University Press. Howden,

Daniel. 2007. Toxic chemicals blamed for the disappearance of Arctic boys. The Independent,

12 September. http://www.independent.co.uk/environment/green-living/toxic-chemicals-blamed-for- thedisappearance-of-arctic-boys-402077.html.

Howe, Adrian. 1991. The problem of privatized injuries: Feminist strategies for litigation. In At the boundaries of law: Feminism and legal theory, ed. Martha Albertson Fineman, and Nancy Sweet Thomadsen, 148-167. New York: Routledge.

Hubbard, Ruth. 1997. Abortion and disability. In The disability studies reader, ed. Lennard J. Davis, 187-202. 
New York: Routledge.

Jain, Sarah. 2006. Injury: The politics of product design and safety law in the United States. Princeton, NJ: Princeton University Press.

Jain, Sarah Lochlann. 2007. Cancer butch. Cultural Anthropology 22: 501-538.

Krupp, Staci Jeanne. 2000. Environmental hazards: Assessing the risk to women. Fordham Environmental Law Journal 12: 111-138.

Kukla, Rebecca. 2005. Mass hysteria: Medicine, culture, and mothers' bodies. Lantham, MD: Rowman \& Littlefield Publishers.

Langston, Nancy. 2008. The retreat from precaution: Regulating diethylstilbestrol (DES), endocrine disruptors, and environmental health. Environmental History 13(1): 41-65.

Lazarus, Richard J. 1997. Fairness in environmental law. Environmental Law 27: 705-739.

Luke, Timothy W. 2000. Rethinking technoscience in risk society: Toxicity as textuality. In Reclaiming the environmental debate: The politics of health in a toxic culture, ed. Richard Hofrichter, 239-254. Cambridge, MA: MIT Press.

MacDonald, Elaine, and Sarah Rang. 2007. Exposing Canada's chemical valley: An investigation of cumulative air pollution emissions in the Sarnia, Ontario area. http://www.ecojustice.ca/publications/ reports/report-exposing-canadas-chemical-valley/attachment. Accessed 18 Sept. 2009.

Mackenzie, Constance A., Ada Lockridge, and Margaret Keith. 2005. Declining sex ratio in a First Nation community. Environmental Health Perspectives 113: 1295-1298.

MacKinnon, Catharine A. 1979. Sexual harassment of working women. New Haven, CT: Yale University Press.

Martin, Aryn. 2009. "Your mother's always with you": Material feminism and fetomaternal microchimerism. Resources for Feminist Research forthcoming.

Mellor, Mary. 1997. Feminism \& ecology. New York: NYU Press.

Mitchell, Gary. 2004. Predominance of female babies on Niue Island - a sign of endocrine disruption? Journal of Rural and Remote Environmental Health 3: 29-39.

Mittelstaedt, Martin. 2008. Humanity at risk: Are the males going first? Globe \& Mail, F4, 20 September.

Mostafa, Randa M., Z. Mirghani, K.M. Moustafa, Y.M. Moustafa, and M.H. El Hefnawi. 2007. New

chapter in old story: Endocrine disruptors and male reproductive system. Journal of Medical Sciences Research 2: 33-42.

Nolan, Donal. 2007. New forms of damage in negligence. Modern Law Review 70: 59-88. Nye,

Jennifer L. 1998. The gender box. Berkeley Women's Law Journal 13: 226-256.

Oudshoorn, Nelly. 1994. Beyond the natural body: An archeology of sex hormones. New York: Routledge.

Prialux, Nicky. 2004. That's one heck of an "unruly horse"! Riding roughshod over autonomy in wrongful conception. Feminist Legal Studies 12: 317-324.

Roberts, Dorothy E. 1991. Punishing drug addicts who have babies: Women of color, equality and the right of privacy. Harvard Law Review. 104: 1419-1482.

Scott, Dayna Nadine. 2008. Confronting chronic pollution: A socio-legal analysis of risk and precaution. Osgoode Hall Law Journal 46: 293-346.

Sheth, Darpana M. 2006. Better off unborn? An analysis of wrongful birth and wrongful life claims under the Americans with Disabilities Act. Tennessee Law Review 73: 641-666.

Shildrick, Margrit. 1997. Leaky bodies and boundaries: Feminism, postmodernism and (bio)ethics. London: Routledge.

Smith, Linda Tuhiwai. 1999. Decolonizing methodologies: Research and indigenous peoples. London: Zed Books.

Solomon, Gina M., and Ted Schettler. 2000. Environment and health: Endocrine disruption and potential human health implications. Canadian Medical Association Journal 163: 1471-1476.

Steingraber, Sandra. 1991. We all live downwind. In 1 in 3: Women with cancer confront an epidemic, ed. Judy Brady, 36-48. Pittsburgh: Cleis Press.

Tremain, Shelley. 2002. Theoretical perspectives on the construction of the gendered body and disability. In Head, heart and hand: Partnerships for women's health in Canadian environments, ed. Penny Van Esterik, 455-486. Toronto: National Network on Environments and Women's Health.

Verchick, Robert R.M. 1996. In a greener voice: Feminist theory and environmental justice. Harvard Women's Law Journal 19: 23-88.

West, Robin. 1988. Jurisprudence and gender. University of Chicago Law Review 55: 1-72. West,

Robin. 1997. Caring for justice. New York: NYU Press.

Witting, Christian. 2002. Physical damage in negligence. Cambridge Law Journal 61: 189-208.

Witting, Christian. 2008. The house that Dr Beever built: Corrective justice, principle and the law of negligence. Modern Law Review 71: 621-640. 